\title{
Role of Leeches in Peri-orbital lacerations healed by primary intention
}

\author{
Case Report
}

\author{
Dhyan Surendranth ${ }^{1 *}$, Prasanna N Rao ${ }^{2}$, Gopikrishna BJ ${ }^{3}$, Avnish Pathak ${ }^{4}$ \\ 1. PG Scholar, 2. Professor \& Principal, 3. Professor \& HOD, 4. Associate Professor \\ Department of Shalya Tantra, \\ Sree Dharmasthala Manjunatheshwara College of Ayurveda \& Hospital, Hassan
}

\begin{abstract}
Leeches have been liberally used throughout the ages and in the field of medicine, holds no exception. Right since the dawn of medicine, leeches have always held a major role in varying strata of treatment. The periorbital region on the face is a delicate area susceptible to oedema, discoloration and pain when subjected to any trauma which requires lengthy duration to retrieve back to normalcy. This period of time could be troublesome for the patient cosmetically, emotionally and socially. Hence in the present study, Leeches were employed in Peri orbital lacerations which were healed by primary intention. It was seen, that cases wherein leeches were used, showed faster resolution in edema, pain, discoloration as compared to not having any leech intervention.
\end{abstract}

Keywords : Leech therapy, Jalouka, Periorbital laceration, Wound healing

\section{Introduction}

"Healing is a matter of time, but it is sometimes also a matter of opportunity." Hippocrates

\section{Wound Healing and the Inflammatory Response}

Wounds, whether closed by primary intention, subject to delayed primary closure or left to heal by secondary intention (1), heal by a dynamic process which can be divided into three phases:

\section{+ Inflammatory phase \\ + Proliferation phase/ Tissue Formation \\ + Maturation phase/ Tissue Remodelling (2)}

In the inflammatory phase, after initial wounding, platelet aggregation is followed by infiltration of leukocytes, various growth factors, enzymes and nutrients into the wound site. The characteristic signs of inflammation namely rubor, calor, dolor, tumor and functio laesa are seen at this stage.

In the tissue formation phase, new granulation tissue, which is comprised of collagen and extracellular matrix, is formed and a new network of blood vessels develop in a process called angiogenesis. The color and condition of the granulation tissue is often an indicator of how the wound is healing, healthy granulation tissue being granular and uneven in texture. It does not bleed easily and is pink / red in color. Epithelial cells finally resurface to restore tissue integrity in a process called epithelialization.

\section{*Corresponding Author:}

\section{Dhyan Surendranth}

PG scholar, Department of Shalya Tantra,

Sree Dharmasthala Manjunatheshwara College of

Ayurveda \& Hospital, Hassan

Mobile No. +91-9164353330

E-mail: dhyan88@gmail.com
The final phase is maturation, which involves the remodeling of collagen from type III to type I and occurs once the wound has closed.

Thus, tissue injury invariably evokes an inflammatory response. But, the dogma that inflammation is essential for efficient tissue repair $(3,4)$ has been challenged in recent times even as information regarding the specific subsets of inflammatory cell lineages and the cytokine network keeps accumulating. In fact, some experimental models of repair show that inflammation delays healing and results in increased scarring. Furthermore, chronic inflammation, a hallmark of the non-healing wound, predisposes tissue to cancer development. (5)

Resolution of the inflammatory response is essential for successful wound repair. Resolution of inflammation is directed by down regulation of proinflammatory mediators and the reconstitution of normal microvascular permeability, which contributes to the cessation of local chemo attractants, synthesis of anti-inflammatory mediators, apoptosis, and lymphatic drainage. An excessive or prolonged inflammatory response results in increased tissue injury and poor healing. Successful wound repair therefore, requires the coordinate expression of both inflammation and resolution of inflammation.

\section{Eyelid lacerations}

Eyelid trauma often presents some frustrating challenges to the surgeon. Proper management of eyelid lacerations requires a thorough knowledge of the anatomy of the eyelids and periorbital structures, careful examination for associated ocular injury, and prompt referral to a specialist when complications are encountered.

Since the eyelids and the periorbital area are extremely important to facial aesthetics, one must exercise utmost care while dealing with trauma in this 
region. The skin is thin, loose and mobile over the deeper structures and becomes coarser, thicker and more sebaceous lateral to the bony margin. The upper eye lid skin is well vascularized and healing occurs quickly with favorable scar formation.

It may be necessary to use a combination of skin grafts and lid sharing techniques if primary closure is not possible. The complications that can arise may include orbital hemorrhage, ectropion, milia, lagopthalmos and even blindness.

The laceration may be isolated or in continuation with an eyebrow injury. The skin in the eye brow region being thicker than the eyelid requires at least a twolayer closure. (6)

\section{Periorbital anatomy}

Unlike other parts of the body, the skin over the face (except over the Parotid gland and the masseter muscle which is covered by the parotidomassetteric fascia) has no distinct deep fascia and the subcutaneous tissue between the cutaneous attachments of the fascial muscles is loose.

The skin over the periorbital region is the thinnest compared to other parts of the body.

The second layer, subcutaneous areolar tissue is devoid of fat, so is prone to distention by edema or blood (ecchymosis).

The layer below the areolar tissue is the layer of striated muscles which consists of the_orbicularis oculi muscle, which is an oval sheet across the eyelid that helps in closing of the eye lid. Levator palpebral superioris muscle helps to raise the upper lid

The sub muscular areolar tissue is a layer of loose connective tissue where nerves and vessels lie.

A fibrous layer lies below the sub muscular areolar layer which acts as a frame work for the lids and consist of two parts - central tarsal plate and peripheral septum.

The final layer is of the non striated muscle fibres consisting of palpebral muscle of muller. (7)

\section{Leeches in Medicine}

Leeches have been used in medical applications for thousands of years. References of medicinal leeching can be found in the paintings of Pharaohs in the $18^{\text {th }}$ dynasty $(1500 \mathrm{BC})$. Talmud, Bible, and other Jewish manuscripts have outlined the medical indications of leeching (8)

The use of leeches during that time depended upon the humor concept of Galen (130-201 AD), which was inspired from Hippocrates (460-370 BC) hypothesis about illness caused due to imbalances in body fluids. (9)

Galen prescribed bloodletting by leech for almost all illnesses such as simple inflammatory conditions, mental disorders and hemorrhoids. (10)Avicenna recommended leeching for skin diseases Abd-el-latif al -Baghdadi (12 $2^{\text {th }}$ century) has mentioned the beneficial use of leech application after surgical operations in his texts. (11)

Haycraft's researches brought leeches back into the medical stream when he outlined for the first time the presence of an anticoagulant agent in leech saliva, which he called hirudin(12) which was later isolated and identified by Markwardt who also demonstrated its antithrombin activity.

The use of leeches for medicinal purposes has been approved by the Food and Drug Organization (FDA) in 2004 (2) The most commonly used leech is the European medicinal leech species, Hirudo medicinalis. (13)

\section{Use of leeches in surgery}

In plastic surgeries, venous occlusion is a serious threat that may lead to thrombus formation, stasis, and eventually tissue necrosis. Thus, relieving venous congestion is a vital step in order to mitigate this risk and to salvage the transplanted tissues (14). The relieving effect is the accumulated result of the leech bite-induced blood oozing, which is a consequence of many factors, including bleeding wound, secreted bioactive enzyme, anticoagulants, and vasodilators.

Leeching has been reported as a successful remedy to improve blood flow after microsurgery of a severely avulsed scalp. (15) By the year 1984, some physicians used leech therapy to treat seven patients with engorged skin flaps. They reported that leeching prevented flap collapse with noticeable improvement in color and minor complications (16). Leech application was prescribed as a postoperative care in patients who underwent a surgical operation for replantation of the fingertip (17).

The painkiller effects of leech application were ascertained in many trials on patients with osteoarthritis who claimed that leeching was more relieving than topical diclofenac with no adverse effects (18)

\section{Ayurveda aspects of Jalouka (leech).}

Acharya Sushruta has given a detailed account of Leeches in his text, Sushruta Samhita in Sutra Shana wherein he describes the etymology, habitat, types along with morphology to assist in identifying the suitable variety for treatment applicability, the methodology for leech therapy and the aftercare for leeches to promote its longevity. (19)

In non healing ulcers caused by venom or poisons, leeches are a preferred mode of blood letting to induce healing. (20)

In the treatment of abscesses, certain glandular inflammatory swellings, inflammed scrotal swellings, Acharya Sushruta has indicated Jaloukavacharana (leech therapy) as a prerequisite for incision and drainage in order to localize the abscess $(21,22,23,24$, 25)

In the general line of treatment of venereal disorders, the use of leeches have been emphasized, and in a range of disorders of the penis, leeches acquire a prime role for treatment. $(26,27)$

In inflammatory conditions pertaining to oral cavity, the use of leeches have been described. (29)

Acharya Dalhana, commenting on Saptopakrama (7 forms of treatment for swelling) states that Avasechana includes Vamana (therapeutic emesis), 
Virechana (therapeutic purgation) and Raktha Mokshana (Blood letting) wherein Jaloukavacharana is one among the many forms of blood letting.

\section{Case studies}

Three cases have been selected for this study.

\section{Subject 1}

The first subject was a 9 year old girl who visited the outpatient department with a 1 hour old lacerated wound on her left infra orbital eyelid involving lateral canthus measuring $3 \mathrm{x}$

$1 \mathrm{~cm}$, with a history of shattered wind shield injury. After complete evaluation, the wound was then sutured and allowed to heal with primary intention. The patient was then asked to come back for follow up every day for a week. (Fig. 1 \& Fig. 2)
Figure 1:

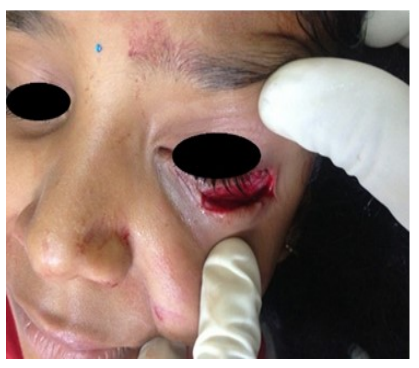

Figure 2:

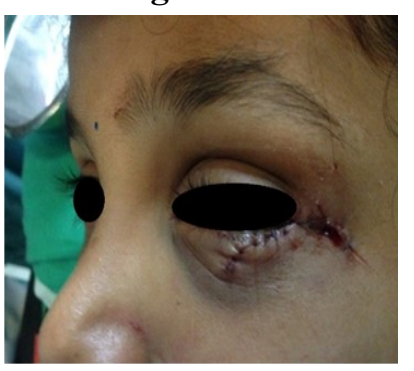

\section{Subject 2}

The second study, comprised of a 26 year old male who presented to the out patient department following a lacerated wound located below his right lower eye lid extending to the right supra alar crease, measuring $5 \times 1 \mathrm{~cm}$. (Fig. 3 \& Fig. 4). The wound was thoroughly irrigated and cleansed after which primary closure was carried out. The patient was then asked to review every day for a week and after 3 days leech therapy was to be carried out.
Figure 3:

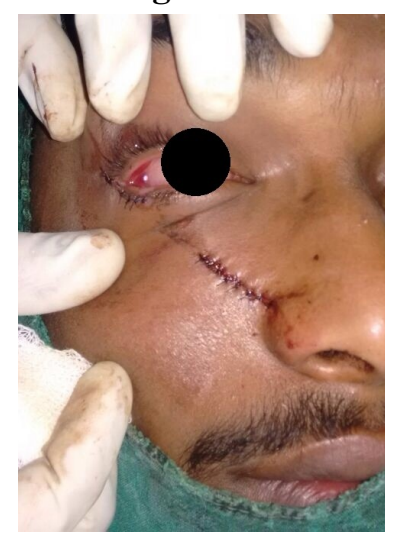

\section{Figure 4:}

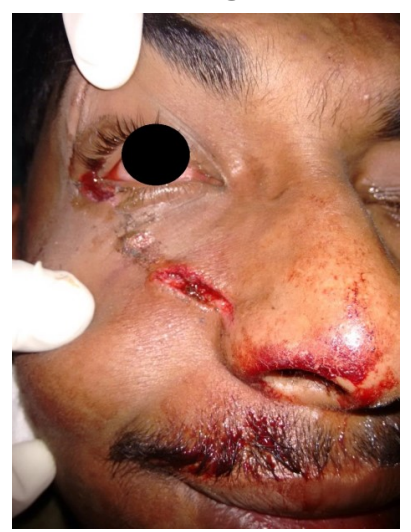

\section{Subject 3}

The third study was a 29 year old male who met with a road traffic accident suffering from multiple abrasions and two lacerated wounds, one lateral to the lateral canthus of the right eye extending upto the right lateral border of the right eye brow measuring $5 \times 2 \mathrm{~cm}$ and the other was below the lateral canthus measuring $2.5 \times 1$ cm. (Fig. 5 \& Fig. 6 )
Figure 5:

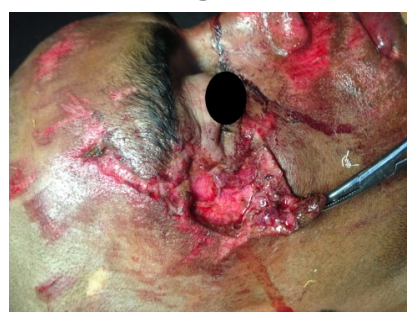

Figure 6:

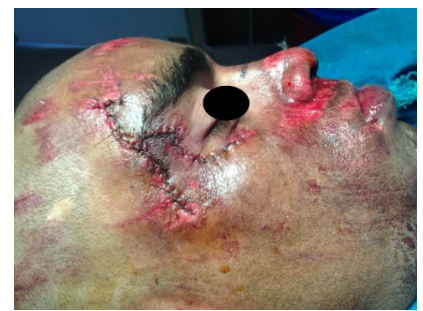

After proper wound toileting and primary closure, the patient was asked to follow up every day for a week and leech therapy was planned after 3 days.

\section{On 3rd day}

Subject 1 was kept as control, hence no leech therapy was carried out. She presented with pain, edema, blackish discoloration and inability to open her eyelid completely. (Fig. 7)

Figure 7:

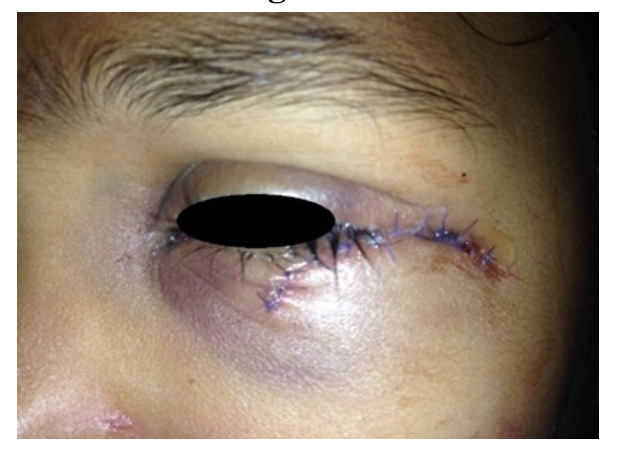

\section{Jaloukavacharana (leech therapy in subject $2 \& 3$ on $3^{\text {rd }}$ day )}

Subject 2 came back for follow up after 3 days and he presented with mild edema and discolouration in his peri orbital region along with subconjuctival hemorrhage. (Fig. 8)

The area was mopped with normal saline to prevent any odor that could inhibit the leech from latching. The leech was then introduced to the site and latching was carried out. (Fig. 9)
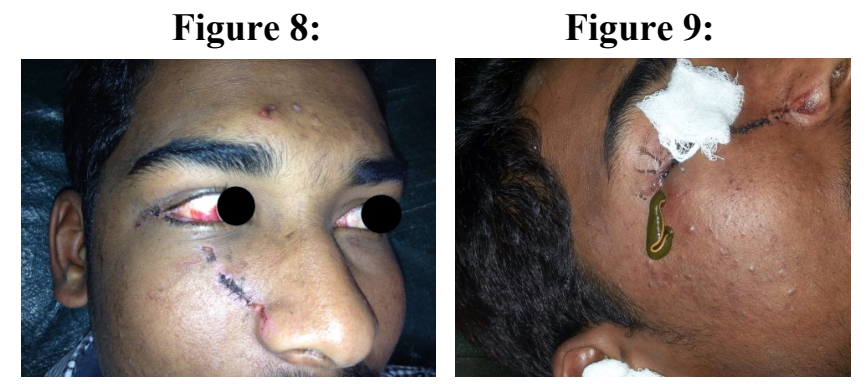

After 45 minutes, the leech withdrew by itself and the required post operative care was carried out for the leech as mentioned in Sushruta Samhita.

Subject 3 reviewed after 3 days and had considerable periorbital swelling, pain and chemosis. (Fig. 10 \& Fig. 11).

Leech therapy was then carried out and the leech had latched on for 1 hour and 15 minutes before it 
withdrew (Fig. 12). The post operative procedures for the leech were then carried out as before.

Figure 10:
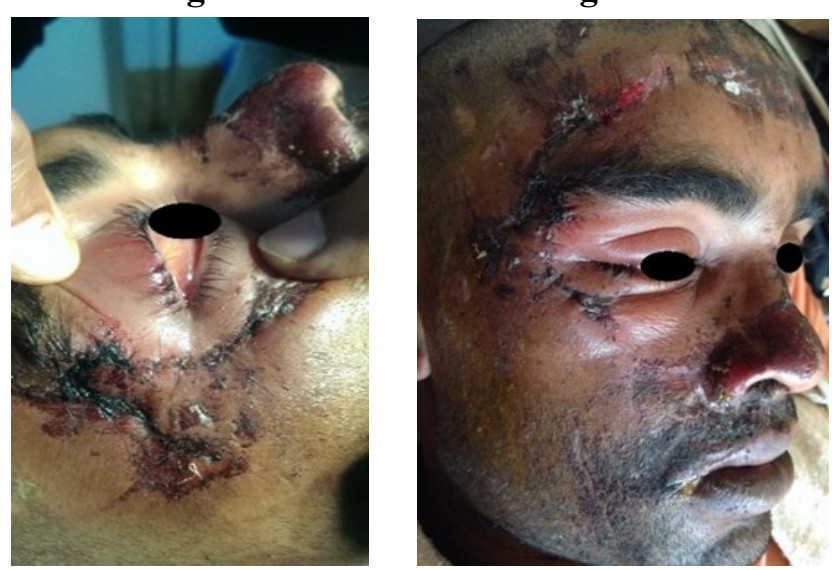

Figure 12:

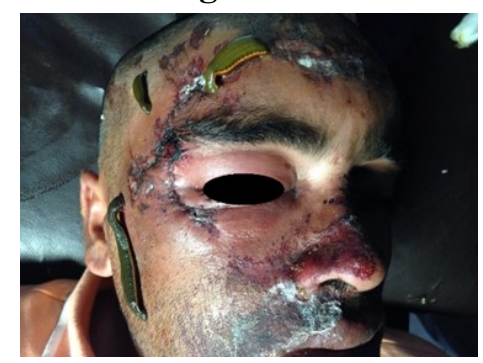

\section{Follow up (after 8 days)}

Subject 1 (without leech intervention)

Discoloration, mild edema and pain were still persisting even after 8 days (Fig.13) and discoloration persisted even upto 20 days.

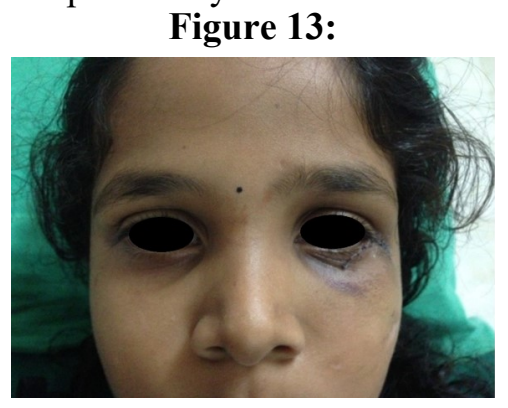

Subject 2 (With leech intervention)

Discoloration, pain, edema and the subconjuctival hemorrhage had subsided.(Fig.14)

Figure 14:

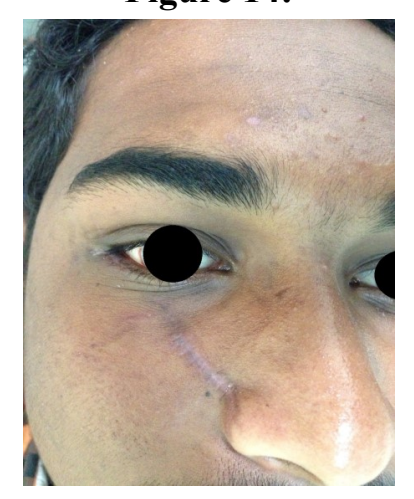

Subject 3 (with leech intervention)

Discoloration, pain, edema and chemosis reduced significantly.(Fig.15)

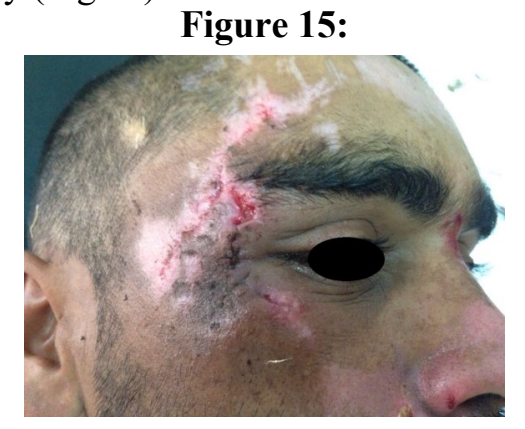

\section{Discussion}

From the above three case studies, leech therapy was carried out in subject 2 and 3 whereas subject 1 was kept as control.

After 8 days, there was persistence of edema, discoloration and pain in subject 1 whereas there was decrease in the symptoms in the other two cases.

It was also additionaly found that even subconjuctival hemorrhage which would otherwise take 3 weeks to subside, had reduced in just a matter of 8 days along with chemosis.

Even though Inflammation is a physiological state of wound healing, it seems to be evident, that by leech therapy, a faster resolution of the inflammatory process, infact helps the wound to heal faster.

A similar study by Sabine A Eming, Thomas Krieg and Jeffrey M Davidson published in the Journal of investigative dermatology (2007) entitled Inflammation in wound repair: molecular and cellular mechanisms, Eming SA, Krieg T, Davidson JM: Inflammation in wound repair: molecular and cellular mechanisms. J Invest Dermatol has shown that in experimental models of repair, inflammation leads to delay in healing and result in increased scarring.

Leeches are a great boon to cosmetology and plastic surgery for their use ensures better acceptability of grafts, flaps and reduced occurrence of scar.

Leech therapy is suitable in all inflammatory conditions arising from trauma, infection or poison/ venom.

Leech therapy is a good alternative in inflammatory conditions as there are no systemic side effects as in the use of conventional medication.

There is no pain experienced by the patient and no known history of allergic reactions ensures greater approvability on the part of the patients.

Since the leeches are reused after their dormancy period, it also proves to be a cost effective approach.

\section{Challenges faced during leech therapy}

- It was noted that on certain occasions, the leech would refuse to latch on and sometimes, it would latch on but refused to suck blood. The reason for this peculiar behavior is still unknown.

- Some patients are apprehensive regarding leech therapy and requires lot of councelling. Some patients would completely avoid the treatment for 
the same cause.

- Any odors of ointment/oils etc. near the site of leech application has a strong negative effect on the leech as it prevents it from latching.

\section{Conclusion}

Leech therapy is a simple method of blood letting. It is also a convenient para surgical procedure that can be employed in varying instances.

Leech therapy in periorbital lacerations healed by primary intention helps in reducing edema, ecchymosis, chemosis, subconjuctival hemorrhage and pain and thereby facilitating early opening of eyelids.

There is potential for further investigative study in the role of leeches in the mechanism of wound healing.

\section{References}

1) Leaper DJ, Harding KG, eds. Wounds: biology and management. Oxford: Oxford University Press, 1998

2) Hutchinson J (1992). The Wound Programme. Centre for Medical Education: Dundee.

3) Simpson DM, Ross R (1972) The neutrophilic leukocyte in wound repair. A study with antineutrophil serum. J Clin Invest 51:2009$2023|\underline{\text { PubMed }}| \underline{\text { ISI }}|\underline{\text { ChemPort }}|$

4) Leibovich SJ, Ross $\mathrm{R}$ (1975) The role of the macrophage in wound repair.Am J Pathol 78:71100 | PubMed | ISI | ChemPort |

5) Eming SA, Krieg T, Davidson JM: Inflammation in wound repair: molecular and cellular mechanisms. J Invest Dermatol (in press) [PubMed]

6) Anatomy Course July 10, 2007 Drs. LaBruna and Jourdy Topic: Wound healing, orbit, eye and eyelid anatomy including orbital fissures, optic muscles, optic nerve and its relation to the paranasal sinuses. Anatomy of the nose. http:// www.entnyc.com/anatomy labruna.pdf

7) Moore K L, Dalley AF, Agur A M. Clinically oriented anatomy. $7^{\text {th }}$ ed. New Delhi: Wolters Kluwer; 2013. p.860

8) Knobloch K. Leeches in microsurgery - An evidence-based approach. In: Kini RM, Clemetson KJ, Markland FS, McLane MA, Morita T, editors. Toxins and Hemostasis. Netherlands: Springer Science; 2011. pp. 735-45.

9) Munshi Y, Ara I, Rafique H, Ahmad Z. Leeching in the history - A review. Pak J Biol Sci.2008;11:1650-3. [PubMed]

10) Upshaw J, O’Leary JP. The medicinal leech: Past and present. Am Surg. 2000;66:313-4. [PubMed]

11) Srivastava A, Sharma R. A brief review on applications of leech therapy. Arch Appl Sci Res.2010;2:271-4.

12) Haycraft JB. On the action of a secretion obtained from the medicinal leech on the coagulation of the blood. Proc $\mathrm{R}$ Soc Lond. 1883;36:478-87.

13) Whitaker IS, Rao J, Izadi D, Butler PE. Historical article: Hirudo medicinalis: Ancient origins of, and trends in the use of medicinal leeches throughout history. $\mathrm{Br} \mathrm{J}$ Oral Maxillofac Surg. 2004;42:133-7.[PubMed]

14) Whitaker IS, Cheung CK, Chahal CA, Karoo RO, Gulati A, Foo IT. By what mechanism do leeches help to salvage ischaemic tissues? A review. Br J Oral Maxillofac Surg. 2005;43:15560. [PubMed]

15) Henderson HP, Matti B, Laing AG, Morelli S, Sully L. Avulsion of the scalp treated by microvascular repair: The use of leeches for postoperative decongestion. $\mathrm{Br} \mathrm{J}$ Plast Surg. 1983;36:235-9. [PubMed]

16) Batchelor AG, Davison P, Sully L. The salvage of congested skin flaps by the application of leeches. Br J Plast Surg. 1984;37:35860. [PubMed]

17) Tsai TM, McCabe SJ, Maki Y. A technique for replantation of the finger tip. Microsurgery. 1989;10:1-4.[PubMed]

18) Michalsen A, Klotz S, Lüdtke R, Moebus S, Spahn G, Dobos GJ. Effectiveness of leech therapy in osteoarthritis of the knee: A randomized, controlled trial. Ann Intern Med. 2003;139:724-30. [PubMed]

19) Vaidya Trikamji Acharya J, Ram Acharya "Kavyatirtha" N. Sutrasthana 13. Susruta samhita of Susruta with the Nibandhasangrah Commentary of Sri Dalhanacharya and the Nyayachandrika Panjika of Sri Gayadaacharya on Nidanasthana. 2008 Edition, Varanasi. Chaukhambha surabharati Prakashan; 2008. p.5558.

20) Vaidya Trikamji Acharya J, Ram Acharya "Kavyatirtha" N. Chikitsasthana 1:29. Susruta samhita of Susruta with the Nibandhasangrah Commentary of SRI DALHANACHARYA ASri Dalhanacharya and the Nyayachandrika Panjika of Sri Gayadaacharya on Nidanasthana. 2008 Edition, Varanasi. Chaukhambha surabharati Prakashan; 2008. p.399.

21) Vaidya Trikamji Acharya J, Ram Acharya "Kavyatirtha" N. Chikitsasthana 16:12. Susruta samhita of Susruta with the Nibandhasangrah Commentary of Sri Dalhanacharya and the Nyayachandrika Panjika of Sri Gayadaacharya on Nidanasthana. 2008 Edition, Varanasi. Chaukhambha surabharati Prakashan; 2008. p.464.

22) Vaidya Trikamji Acharya J, Ram Acharya "Kavyatirtha" N. Chikitsasthana 18:8. Susruta samhita of Susruta with the Nibandhasangrah Commentary of Sri Dalhanacharya and the Nyayachandrika Panjika of Sri Gayadaacharya on Nidanasthana. 2008 Edition, Varanasi. Chaukhambha surabharati Prakashan; 2008. p.470.

23) Vaidya Trikamji Acharya J, Ram Acharya "Kavyatirtha" N. Chikitsasthana 19:10. Susruta samhita of Susruta with the Nibandhasangrah Commentary of Sri Dalhanacharya and the 


\section{Dhyan Surendranath et.al., Role of Leeches in peri-orbital lacerations healed by primary intention}

Nyayachandrika Panjika of Sri Gayadaacharya on Nidanasthana. 2008 Edition, Varanasi. Chaukhambha surabharati Prakashan; 2008. p.476.

24) Vaidya Trikamji Acharya J, Ram Acharya "Kavyatirtha" N. Chikitsasthana 20:3. Susruta samhita of Susruta with the Nibandhasangrah Commentary of Sri Dalhanacharya and the Nyayachandrika Panjika of Sri Gayadaacharya on Nidanasthana. 2008 Edition, Varanasi. Chaukhambha surabharati Prakashan; 2008. p.478.

25) Vaidya Trikamji Acharya J, Ram Acharya "Kavyatirtha" N. Chikitsasthana 20:14. Susruta samhita of Susruta with the Nibandhasangrah Commentary of Sri Dalhanacharya and the Nyayachandrika Panjika of Sri Gayadaacharya on Nidanasthana. 2008 Edition, Varanasi. Chaukhambha surabharati Prakashan; 2008. p.479.

26) Vaidya Trikamji Acharya J, Ram Acharya "Kavyatirtha" N. Chikitsasthana 19:25. Susruta samhita of Susruta with the Nibandhasangrah Commentary of Sri Dalhanacharya and the Nyayachandrika Panjika of Sri Gayadaacharya on Nidanasthana. 2008 Edition, Varanasi. Chaukhambha surabharati Prakashan; 2008. p.476.

27) Vaidya Trikamji Acharya J, Ram Acharya "Kavyatirtha" N. Chikitsasthana 21:4,7,9,11. Susruta samhita of Susruta with the Nibandhasangrah Commentary of Sri Dalhanacharya and the Nyayachandrika Panjika of Sri Gayadaacharya on Nidanasthana. 2008 Edition, Varanasi. Chaukhambha surabharati Prakashan; 2008. p.481.

28) Vaidya Trikamji Acharya J, Ram Acharya "Kavyatirtha" N. Chikitsasthana 22:6. SUSRUTA Susruta samhita of Susruta with the Nibandhasangrah Commentary of Sri Dalhanacharya and the Nyayachandrika Panjika of Sri Gayadaacharya on Nidanasthana. 2008 Edition, Varanasi. Chaukhambha surabharati Prakashan; 2008. p.482.

29) Vaidya Trikamji Acharya J, Ram Acharya "Kavyatirtha" N. Sutrasthana 17:27,28. Susruta samhita of Susruta with the Nibandhasangrah Commentary of Sri Dalhanacharya and the Nyayachandrika Panjika of Sri Gayadaacharya on Nidanasthana. 2008 Edition, Varanasi. Chaukhambha surabharati Prakashan; 2008. p.84. 